\title{
Combined biotic and abiotic stress resistance in tomato
}

\author{
Christos Kissoudis • Rawnaq Chowdhury • Sjaak van Heusden • \\ Clemens van de Wiel · Richard Finkers · Richard G. F. Visser • \\ Yuling Bai · Gerard van der Linden
}

Received: 30 September 2014/ Accepted: 16 January 2015/Published online: 30 January 2015

(C) The Author(s) 2015. This article is published with open access at Springerlink.com

\begin{abstract}
Abiotic and biotic stress factors are the major constrains for the realization of crop yield potential. As climate change progresses, the spread and intensity of abiotic as well as biotic stressors is expected to increase, with increased probability of crops being exposed to both types of stress. Shielding crops from combinatorial stress requires a better understanding of the plant's response and its genetic architecture. In this study, we evaluated resistance to salt stress, powdery mildew and to both stresses combined in tomato, using the Solanum habrochaites LYC4 introgression line (IL) population. The IL population segregated for both salt stress tolerance and powdery mildew resistance. Using SNP array marker data, QTLs were identified for salt tolerance as
\end{abstract}

Electronic supplementary material The online version of this article (doi:10.1007/s10681-015-1363-x) contains supplementary material, which is available to authorized users.

C. Kissoudis - R. Chowdhury - S. van Heusden .

C. van de Wiel · R. Finkers - R. G. F. Visser .

Y. Bai · G. van der Linden $(\square)$

Wageningen UR Plant Breeding, Wageningen University

\& Research Centre, Droevendaalsesteeg 1,

6708PB Wageningen, The Netherlands

e-mail: gerard.vanderlinden@wur.nl

C. Kissoudis - R. Chowdhury - S. van Heusden .

C. van de Wiel · R. Finkers · R. G. F. Visser .

Y. Bai - G. van der Linden

Wageningen UR Plant Breeding, Wageningen University \& Research Centre, Droevendaalsesteeg 1, PO Box 386, 6700AJ Wageningen, The Netherlands well as $\mathrm{Na}^{+}$and $\mathrm{Cl}^{-}$accumulation. Salt stress increased the susceptibility of the population to powdery mildew in an additive manner. Phenotypic variation for disease resistance was reduced under combined stress as indicated by the coefficient of variation. No correlation was found between disease resistance and $\mathrm{Na}^{+}$and $\mathrm{Cl}^{-}$accumulation under combined stress Most genetic loci were specific for either salt stress tolerance or powdery mildew resistance. These findings increase our understanding of the genetic regulation of responses to abiotic and biotic stress combinations and can provide leads to more efficiently breeding tomatoes and other crops with a high level of disease resistance while maintaining their performance in combination with abiotic stress.

Keywords Combined stress - Stress interactions · Crosstalk · Phenotypic variation · Ion homeostasis

\section{Introduction}

Crops grown in open fields encounter multiple unfavorable conditions for optimal plant growth and yield, of both abiotic and biotic origin. The ongoing climate change, accelerated by the increase in atmospheric $\mathrm{CO}_{2}$ concentration (Peters et al. 2011), is resulting in an average rise in temperature and decrease in precipitation especially in regions with temperate 
climates (Dai 2013), which further intensifies agricultural land deterioration due to extended periods of drought and an increase in soil salinity (Munns and Tester 2008; Zhao and Running 2010). Moreover, an increase in temperature and ambient $\mathrm{CO}_{2}$ concentration could directly influence plant pathogens spread and geographic distribution. While studies show that on many occasions the effects on pathogenicity are pathosystem-specific (Coakley et al. 1999), the consensus is that elevated temperatures will result in pathogen geographic expansion and enhanced fecundity, increasing the chances for host range expansion and rise of more virulent strains (Garrett et al. 2006; Harvell et al. 2002). As predictions point to increased possibilities of plants encountering abiotic and/or biotic stress, exposure to combined stresses is expected to become more frequent.

The limited data available for plant responses under abiotic and biotic stress combinations point to predominantly negative interactions at the phenotypic level (Mittler 2006; Kissoudis et al. 2014). Increased soil salt concentration results in enhanced susceptibility to soil borne diseases in tomato (Triky-Dotan et al. 2005) and other crop species (Al-Sadi et al. 2010; You et al. 2011), and similar trends are observed under water deficit (Jordan et al. 1984). Observations of the effects of abiotic stress on foliar pathogens are on the other hand mixed, with studies reporting either enhanced (Achuo et al. 2006; Wiese et al. 2004), or decreased resistance (Roubtsova and Bostock 2009; Sanogo 2004). Abiotic stress severity can affect responses to abiotic and biotic stress combinations (Soliman and Kostandi 1998), and therefore the outcome of the interaction may be dependent on the specific environmental conditions under which it occurs.

Indications for stress regulatory crosstalk can be found at the phenotypic level, and are evident as well at the gene expression level (Kissoudis et al. 2014). Recently, the transcriptome of Arabidopsis subjected to combinations of various abiotic and biotic stressors was analyzed (Atkinson et al. 2013; Prasch and Sonnewald 2013; Rasmussen et al. 2013). The striking commonality of all these studies is the unique responses observed under stress combinations that could not be predicted by the response to individual stressors. Moreover it was observed that the response of a significant number of transcripts was cancelled or prioritized under stress combinations in comparison with the individual stress, suggesting antagonistic interactions with potential detrimental effects on plant adaptation under combined stress.

Apart from the characterization of individual genes involved in both abiotic and biotic stress (Asano et al. 2012; Ramírez et al. 2009) and the recent reports on transcriptomic characterization of the response to various stress combinations in Arabidopsis, the genetic architecture of plant response to combinatorial stress has not been investigated.

In this paper we study the interaction between salinity stress and powdery mildew (PM) infection in tomato. Tomato (Solanum lycopersicum L.) possesses unique properties, as it is both an economically important crop, the first vegetable in production in the world (FAOSTAT 2011), and a model plant species, due to its diploid, relatively compact, and recently sequenced genome (Sato et al. 2012) and its large genetic and genomic resources (Ranjan et al. 2012). Tomato productivity is affected by a high incidence of increased soil salinity in the areas of cultivation (Cuartero et al. 2006). Additionally, fungal pathogens can significantly limit productivity by colonizing the foliage or the fruits. The biotrophic ascomycete Oidium neolycopersici (causing PM) is one of the economically most important foliar pathogens of tomato, both in the greenhouse and in open field conditions (Jones et al. 2001).

We evaluated a Solanum habrochaites introgression line (IL) population (accession LYC4 as the donor) in the background of cultivated tomato (cv. Moneymaker, Finkers et al. 2007b) for our study. $S$. habrochaites is native to high altitude habitats in the Andean mountains (Grandillo et al. 2011), and various accessions were used as a source for cold tolerance (Venema et al. 2008) and resistance to a wide range of fungal pathogens (Grandillo et al. 2011) including PM (Huang et al. 2000). The LYC4 population was evaluated previously for Botrytis resistance (Finkers et al. 2007b) and parthenocarpy (Gorguet et al. 2008).

The results presented in this paper show that the LYC4 IL population segregated for both salt stress tolerance and PM resistance. QTLs conferring resistance to the individual stresses were identified using a high density SNP array for accurate localisation of introgressions. In addition the effect of salt stress on the genetic factors involved in PM resistance was evaluated. Various new genetic loci contributing to tomato salt stress tolerance and PM 
resistance were discovered. Salt stress increased susceptibility to PM, reducing phenotypic variation for disease resistance. These results provide novel genetic resources for enhancing salt stress tolerance and PM resistance in tomato and enhance our understanding for plant responses under abiotic and biotic stress combinations.

\section{Materials and methods}

\section{Plant material}

The core collection of a S. habrochaites LYC4 introgression line (IL) population in the genetic background of $S$. lycopersicum cv. Moneymaker (MM), consisting of 31 ILs covering most of the tomato genome, was used in this study (Finkers et al. 2007b). The population was originally generated aiming at maximum coverage of the wild species genome and parts of each chromosome being present in at least three ILs as assessed with AFLP markers. Twenty-nine of the ILs were genotyped using a custom made single nucleotide polymorphism (SNP) Infinium array containing 5,528 SNPs, as described by (Víquez-Zamora et al. 2013). The introgressed regions according to the SNP data were visualized using the software Graphical GenoTypes 2 (Van Berloo 2008).

\section{Experimental conditions and treatments}

Experiments were carried out in the Unifarm greenhouse facilities of Wageningen University \& Research Centre. The photoperiod regime was $16 \mathrm{~h}$ light and $8 \mathrm{~h}$ dark. Greenhouse air humidity was $70 \%$. Additional lighting $\left(100 \mathrm{Wm}^{-2}\right)$ was used if the incoming shortwave radiation was below $200 \mathrm{Wm}^{-2}$.

Tomato seeds were sown in peat and transplanted to $3 \mathrm{~L}$ pots filled with vermiculite. The plantlets were irrigated with half strength Hoagland's nutrient solution every 2 days initially, and every day in the final week of the experiment. Due to spatial restrictions and PM containment measures the simultaneous assessment of all four treatments was not possible, therefore, two subsequent and partially overlapping experiments were carried out. In the first experiment, salt stress was applied to the population by the addition of $100 \mathrm{mM}$ $\mathrm{NaCl}$ to the nutrient solution of 3 weeks-old plants ( 5 plants per line), for 21 days. The pots were watered until leaching, to ensure uniformity of the treatment and to prevent $\mathrm{NaCl}$ accumulation. The concentration of $\mathrm{NaCl}$ in the pots was regularly monitored by measuring the electrical conductivity (EC) of the leachate after the completion of the irrigation.

In the second experiment, PM and combined salt stress-PM resistance were assessed as follows: 3-week old plants (4 plants per line) were watered with a solution containing $100 \mathrm{mM} \mathrm{NaCl}$ for 1 week. Subsequently, PM was applied to both (4-week old) salt stressed and non-salt stressed plants according to (Bai et al. 2003) by spraying a suspension of $5 \times 10^{4}$ conidia.ml $^{-1}$ [prepared by washing conidial spores from leaves of heavily infected (sporulation stage) MM plants]. The plants were grown for another 2 weeks after inoculation.

\section{Traits measured}

Salt stress experiment

Chlorophyll content was measured using a SPAD-502 meter (Minolta, Osaka, Japan) at the third and fourth leaf counting from the bottom, 1 day before harvest. Plant height and shoot fresh weight (FW) were recorded at the end of the experiment. Dry weight was determined after drying the plant tissues in a forced-air oven at $70{ }^{\circ} \mathrm{C}$ until the samples reached stable weight. Salt tolerance index was calculated as the ratio of (fresh or dry) shoot biomass under salt stress and biomass under control conditions for each genotype.

Powdery mildew and combined stress experiment

The disease severity was expressed as disease index (DI), assessed at $12 \mathrm{dpi}$ (days post inoculation). DI was expressed on a scale from 0 to 5 , slightly modified from (Bai et al. 2003), to increase the resolution of infection incidence in order to obtain a more quantitative measure of disease resistance. The values corresponded to macroscopic observations of PM growth and sporulation where $0=$ healthy plant, no visible sporulation, $1=<0.1-10 \%$ of foliar area affected, slight sporulation, $2=10-20 \%$ area affected, $3=20-30 \%$ area affected, $4=30-50 \%$ area affected and $5=>50 \%$ area affected with abundant sporulation. 
Ion chromatography

For the ion content determination the oven-dried leaves of tomato plants were ground to fine powder using a hammer mill with $1 \mathrm{~mm}$ sieve. The powder was ashed at $575{ }^{\circ} \mathrm{C}$ for $6 \mathrm{~h}$. Ashed samples were dissolved by shaking for $15 \mathrm{~min}$ in $1 \mathrm{ml} 3 \mathrm{M}$ formic acid at $99{ }^{\circ} \mathrm{C}$ and then diluted with $9 \mathrm{ml}$ MilliQ water. A final $500 \times$ dilution was subsequently prepared by mixing $0.2 \mathrm{ml}$ sample solution with $9.8 \mathrm{ml}$ MilliQ water. The concentration of $\mathrm{Na}^{+}, \mathrm{K}^{+}, \mathrm{Ca}^{2+}, \mathrm{Mg}^{2+}$ and $\mathrm{Cl}^{-}, \mathrm{PO}_{4}^{3-}$ and $\mathrm{SO}_{4}^{2-}$ of each sample was measured using ion chromatography (IC) system 850 Professional (Metrohm Switzerland). The anions were determined using Metrosap A 150, 150/4.0 mm column equipped with a Metrosap C5/5 Supp 4/6 Guard column and the cations with Metrosap C4 Supp 4, 250/4.0 mm column equipped with a Metrosap A Supp 4/6 Guard column.

Statistical and bioinformatics analyses

Experiments were carried out in a Split plot design with five replications for the salinity stress experiments and four replications for the PM and combined stress experiment. Statistical analyses were performed using Genstat 15th edition. Introgression lines with trait values significantly different from the recurrent parent (MM) were identified using a two-sided Dunnett test (Dunnett 1955) at a type I error rate of $\alpha=0.05$, and the underlying introgression was assigned as a QTL. Correlations between traits were calculated using the Pearson correlation coefficient $(\mathrm{p} \leq 0.05)$. The Coefficient of Variation $(\mathrm{CV}=\mathrm{s} / \overline{\mathrm{x}} \times 100)$ was used to estimate trait phenotypic variation of the population. The discovered QTLs were surveyed for underlying candidate genes with Marker2Sequence software (Chibon et al. 2012) using as input the position of the distal-most SNP markers of the $S$. habrochaites LYC4 introgressed region.

\section{Results}

Genotyping of ILs

The custom made, Illumina Infinium based array described in (Víquez-Zamora et al. 2013) was used for the genotyping of the $S$. habrochaites LYC4 ILs. 1,508 SNPs out of 5,528 (27.2\%) were polymorphic between the $S$. lycopersicum and $S$. habrochaites LYC4 parental lines after SNP filtering with the quality control criteria (Víquez-Zamora et al. 2013, Supp. Table 1). The markers were landmarked on the genomic sequence of tomato (Víquez-Zamora et al. 2013), which facilitated precise localization of the introgressions of interest and subsequent investigation of underlying putative candidate genes located in the introgressed regions. As expected the size of the introgressions in many occasions deviated significantly on what was predicted by the genetic distances examined previously with AFLP markers (Finkers et al. 2007b). On some occasions (such as in ILs 2-3 and 8-2) introgression were revealed in different chromosomes compared to the ones originally assigned (Supp. Table 1; Supp. Fig. 1). However as these are only a handful of exceptions we maintained the naming of the lines of the population as reported previously (Finkers et al. 2007b).

Variation in phenotypic traits

Solanum habrochaites LYC4 (LYC4) was selected from different tomato wild species and tomato breeding lines that were evaluated for salt tolerance and powdery mildew (PM) resistance. LYC4 exhibited significantly higher salt Tolerance index (calculated as the ratio of total above ground FW under salinity stress and that under control conditions, expressed as percentage, $74.2 \%$ compared to $56.5 \%$ of $\mathrm{MM}$ ), and was highly resistant to PM (DI score of 0.7 compared to 4 of MM). Therefore, the S. habrochaites LYC4 IL population in the background of $S$. lycopersicum cv. MM as described in (Finkers et al. 2007b) was chosen for this study.

The frequency distribution of the population growth (total above ground fresh biomass) under non-stress conditions revealed a normal distribution (Shapiro-Wilk test, $\mathrm{p}=0.903$ ) after excluding LYC4, which had significantly lower biomass than the population (Fig. 1a). Similarly, relative FW under salt stress (salt tolerance index-see below) followed a normal distribution (Shapiro-Wilk test, $\mathrm{p}=0.267$ ) (Fig. 1b). Interestingly, the majority of the population exhibited increased salt stress tolerance compared to the recurrent parent (MM). 
Fig. 1 Frequency distribution of: a shoot FW under control conditions, b relative shoot $\mathrm{FW}$ under salt stress $100 \mathrm{mM} \mathrm{NaCl}$ (salt tolerance index), c PM resistance under control conditions, d PM resistance under salt stress $(100 \mathrm{mM}$ $\mathrm{NaCl}$ ) of the 31ILs and the two parental lines of the $S$. habrochaites LYC4 population. The mean values of the two parental lines are indicated by arrows (a)
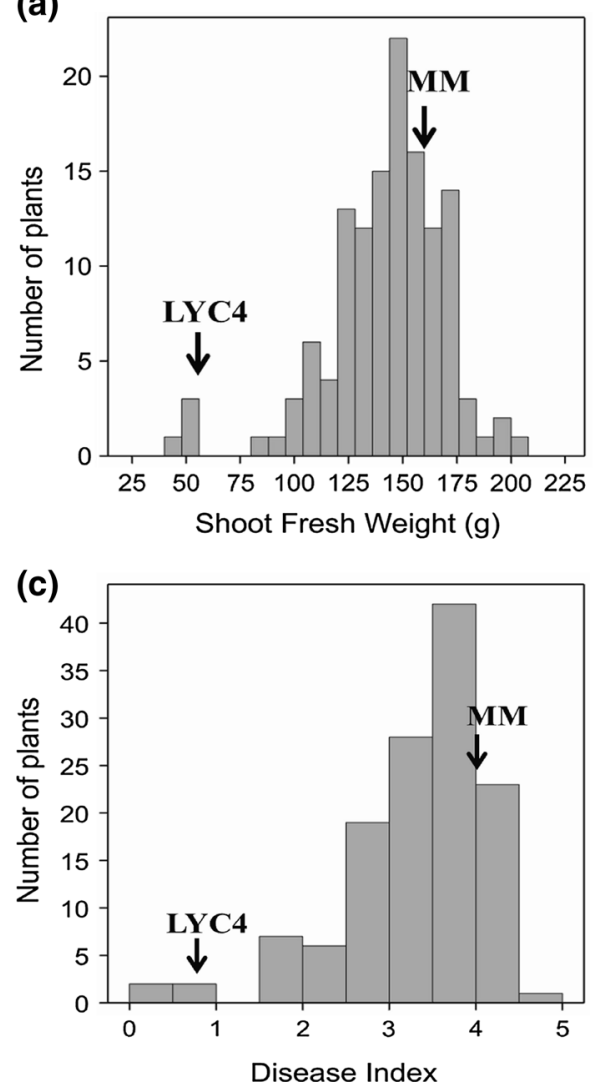

(b)

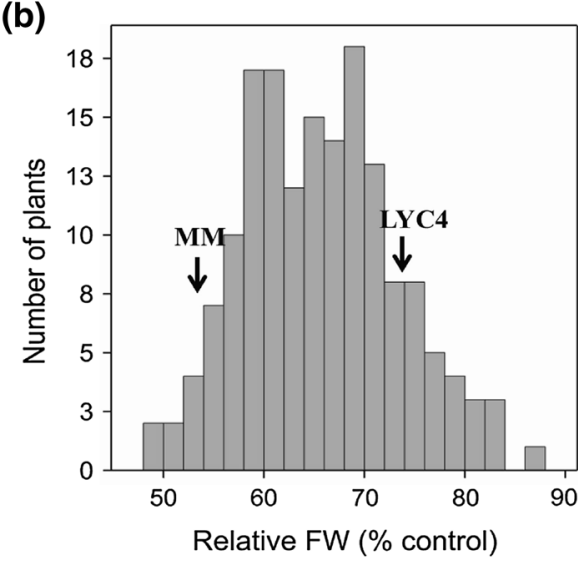

(d)

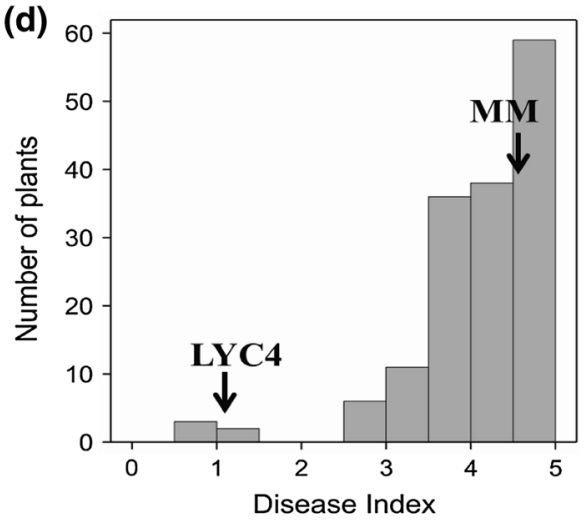

On the other hand, the disease index (DI) frequency distribution deviated from normality, exhibiting negative skewness. This was due to the majority of the individuals of the population being susceptible to PM, and none exhibiting the level of resistance of the donor parent LYC4 (Fig. 1c). DI frequency distribution under combined salt stress and PM was similarly negatively skewed, but with an increased degree of skewness indicating that salt stress further enhanced disease susceptibility (Fig. 1d).

Identification of QTLs for salt tolerance and ion accumulation

FW and DW under salt stress were highly correlated $(\mathrm{r}=0.9, \mathrm{p}<0.0001)$, however variation between ILs was more pronounced for FW. Therefore, salt tolerance index was determined as ratio of total above ground FW under salinity and FW under control conditions expressed as percentage, normalizing the differences in growth of the different genotypes under control conditions.
Ten ILs (IL1-2, IL1-4, IL2-3, IL3-2, IL4-2, IL8-2, IL9-1, IL10-2, IL10-3, IL10-4) exhibited higher salt tolerance index compared to the recurrent parent MM (Dunnett test, $\mathrm{p}<0.05$, Fig. 2a, Table 1). Salt tolerance of those lines ranged from 67 to $80 \%$ maintenance of growth under saline conditions compared to $56.5 \%$ of MM, with IL8-2 exhibiting the highest degree of tolerance. Among those lines, IL2-3 and IL3-2 additionally exhibited significantly higher FW compared to the recurrent parent under salt stress (108.7 and $113.2 \mathrm{~g}$, respectively, compared to $89 \mathrm{~g}$ for MM).

Putative QTLs for salt tolerance reside in the introgressed regions of the salt tolerant lines. Several lines carried large introgressions, covering almost complete chromosomes (e.g. ILs 2-3, 3-2 and 8-2), and therefore pinpointing underlying candidate genes from the numerous genes in these introgressions is not possible. Shared introgressions between different ILs conferring salt tolerance provides a strong and more precise indication for a QTL. Both ILs 1-4 and 9-1 carried a $\sim 4 \mathrm{Mbp}$ introgression at the top of Chr. 9, 
Fig. 2 Graphical genotypes and the respective performance of ILs significantly different to the recurrent parent (MM) for: a salt stress tolerance, b PM resistance under control conditions, c PM resistance under salt stress. The $S$. habrochaites LYC4 introgressed segments are depicted as dark (homozygous) and light (heterozygous) blue squares in MM genetic background (orange). (Color figure online)
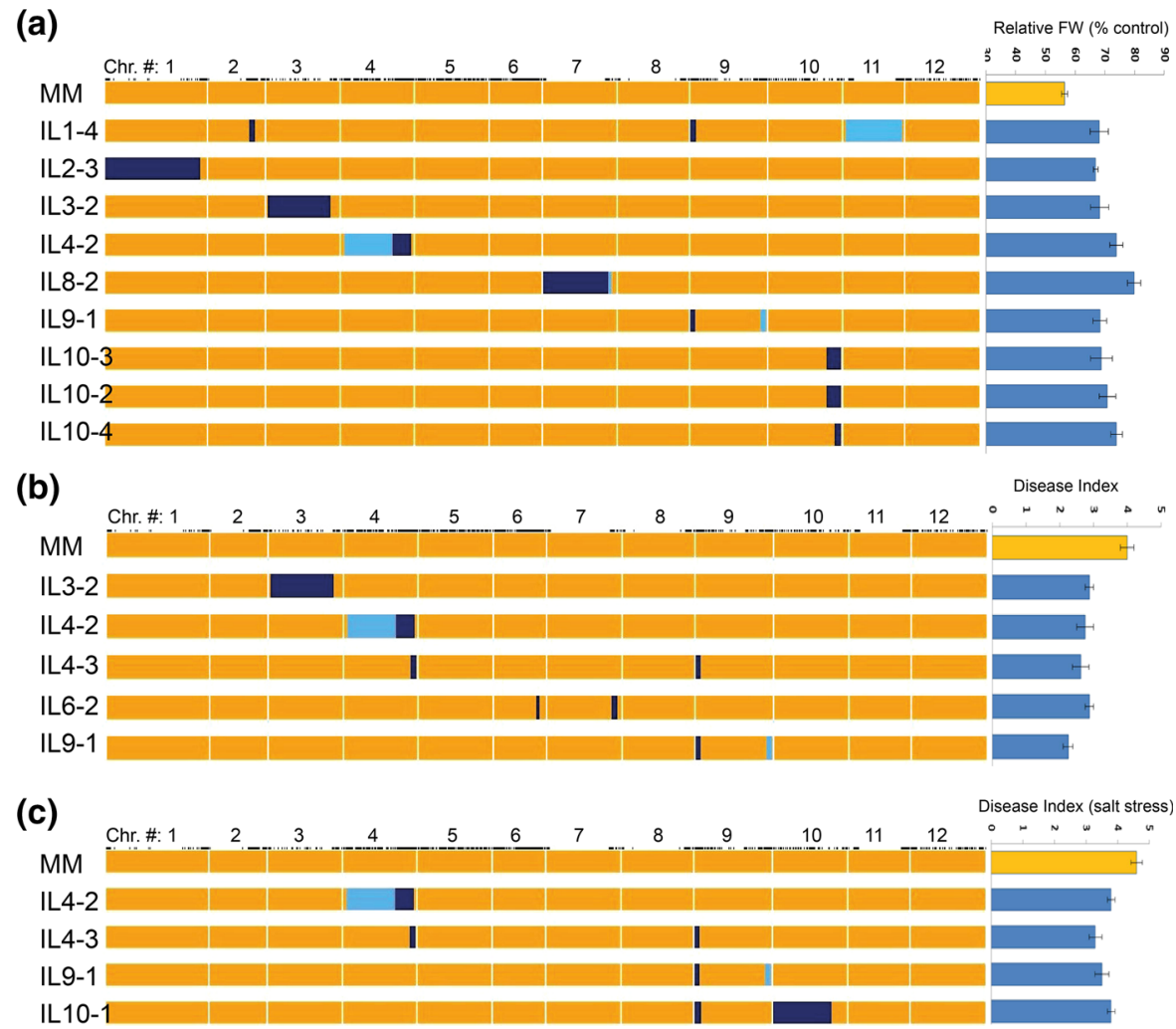

while a common overlapping region of $\sim 2.7 \mathrm{Mbp}$ at the bottom of Chr. 10 was shared between ILs 10-2, 10-3 and 10-4.

As ion toxicity in the shoot is an important aspect of salt stress, the population was profiled for ion concentrations in shoots under both control and salt stress conditions. The genetic effects of introgressions on variation in concentrations of the macronutrients $\mathrm{Na}^{+}, \mathrm{Cl}^{-}, \mathrm{K}^{+}, \mathrm{Ca}^{2+}, \mathrm{Mg}^{2+}, \mathrm{PO}_{4}^{3-}$ and $\mathrm{SO}_{4}^{2-}$ and the consequences for salt tolerance and DI were investigated (Table 2). No significant differences in ion concentrations were identified between the ILs and MM under control conditions. Under salt stress, introgression lines IL12-1 and IL12-3 accumulated significantly less $\mathrm{Na}^{+}$compared to MM (18.2 and 18.6 compared to $25.5 \mathrm{mg} / \mathrm{g}$ dry biomass respectively, Table 1). IL12-3 was not genotyped with the SNP array, however using the AFLP data from Finkers et al. (2007b), the introgressed region was shown to overlap with that of IL12-1. Therefore a common genetic factor potentially underlies the reduced $\mathrm{Na}^{+}$accumulation in those lines. IL8-2 and IL12-3 accumulated significantly less $\mathrm{Cl}^{-}$compared to MM (30.1 and 28.2 compared to $41.6 \mathrm{mg} / \mathrm{g}$ dry biomass respectively). $\mathrm{K}^{+}$ concentration was significantly higher in IL9-1 (33.0 compared to $25.2 \mathrm{mg} / \mathrm{g}$ dry biomass in $\mathrm{MM}) . \mathrm{K}^{+} / \mathrm{Na}^{+}$ ratio, considered to be an indicator for salt tolerance (Shabala and Cuin 2008), was significantly increased in the lines IL2-3, IL6-3, IL9-1, IL12-3 and IL12-1 compared to MM. Finally, except for $\mathrm{SO}_{4}^{2-}$ in IL3-1 which exhibited a significantly higher content ${ }^{-}, \mathrm{Ca}^{2+}$, $\mathrm{Mg}^{2+}$ and $\mathrm{PO}_{4}^{3-}$ concentrations were not significantly different in any of the ILs under salt stress.

\section{Correlation analyses}

Correlation analysis (Pearson r, p < 0.05) under control conditions revealed a positive correlation between $\mathrm{FW}$ and $\mathrm{SO}_{4}^{2-}$ concentration $(\mathrm{r}=0.61)$ and a negative correlation with $\mathrm{PO}_{4}^{3-}$ concentration $(\mathrm{r}=-0.43)$. Under salt stress only a few significant correlations were observed (Supp. Table 2). Growth under salt stress was correlated with growth under 
Table 1 Summary of the LYC4 ILs that exhibited significant differences for the different traits measured compared to the recurrent parent MM. The precise location of the introgressed segments carried is provided, as well as previous studies that have identified QTLs for the same trait in the vicinity of those regions and the putative candidate genes present

\begin{tabular}{|c|c|c|c|}
\hline $\begin{array}{l}\text { Introgression } \\
\text { lines }\end{array}$ & Genomic region (s) & References & Candidate genes \\
\hline \multicolumn{4}{|c|}{ Salt tolerance index } \\
\hline IL1-2 & N/A, AFLP data only & & \\
\hline IL1-4 & $\begin{array}{l}\text { Chr2: } 36411532 . .41371688, \text { Chr9: } 48774 . .4715716 \text {, } \\
\text { Chr11: } 64251736 . .51936800 \text { (het) }\end{array}$ & $\begin{array}{l}\text { Li et al. } \\
(2011)\end{array}$ & \\
\hline IL2-3 & Chr1: 25476.. 84030880 & $\begin{array}{l}\text { Li et al. } \\
\text { (2011) }\end{array}$ & NHX3, NHX4,SOS1, Cu/ZnSOD1 \\
\hline IL3-2 & Chr3: 1410013.. 57499392 & $\begin{array}{l}\text { Foolad } \\
\quad(1999)\end{array}$ & \\
\hline IL4-2 & $\begin{array}{l}\text { Chr4: } 3071610 . .44938712 \text { (het), Chr4: } 46110324 . . \\
\quad 61886216\end{array}$ & & \\
\hline IL8-2 & $\begin{array}{l}\text { Chr7: 428378.. 58142204, Chr7: 58189028.. } 60992576 \\
\text { (het) }\end{array}$ & $\begin{array}{l}\text { Asins et al. } \\
\text { (2013) }\end{array}$ & HKT1;1, HKT1;2, \\
\hline IL9-1 & Chr9: 48774.. 3988469, Chr9: 62248928.. 67116024 (het) & & $\begin{array}{l}\text { APX, MDHAR, GRX, ACCox, } \\
\text { EIN2, HSFa3, HSP70 }\end{array}$ \\
\hline IL10-2 & Chr:10: $53339848 . .63662428$ & & \\
\hline IL10-3 & Chr:10: $53339848 . .63662428$ & & \\
\hline IL10-4 & Chr:10: $60924880 . .63662428$ & & $\begin{array}{l}\text { Aquaporin, ERF1,10, Peroxidase, } \\
\text { GST }\end{array}$ \\
\hline \multicolumn{4}{|c|}{$\mathrm{Na}^{+}$content (salt stress) } \\
\hline IL12-1 & Chr12: $161288 . .52930616$ & $\begin{array}{l}\text { Huertas et al. } \\
\text { (2012) }\end{array}$ & SOS2 \\
\hline IL12-3 & N/A, AFLP data only & & \\
\hline \multicolumn{4}{|c|}{$\mathrm{Cl}^{-}$content (salt stress) } \\
\hline IL8-2 & $\begin{array}{l}\text { Chr7: 428378.. 58142204, Chr7: 58189028.. } 60992576 \\
\text { (het) }\end{array}$ & & \\
\hline IL12-3 & N/A, AFLP data only & & \\
\hline \multicolumn{4}{|c|}{$\mathrm{K}^{+}$content (salt stress) } \\
\hline IL9-1 & Chr9: 48774.. 3988469, Chr9: 62248928.. 67116024 (het) & & $\begin{array}{l}\mathrm{K}^{+} \text {channel, Cyclic nucleotide gated } \\
\text { channel }\end{array}$ \\
\hline \multicolumn{4}{|c|}{$\mathrm{K}+/ \mathrm{Na}+$ ratio (salt stress) } \\
\hline IL2-3 & Chr1: $25476 . .84030880$ & & NHX3, NHX4,SOS1 \\
\hline IL6-3 & Chr6: $40011792 . .43431840$ & & $\mathrm{H}^{+}$-ATPase \\
\hline IL9-1 & Chr9: 48774.. 3988469, Chr9: 62248928.. 67116024 (het) & & $\begin{array}{l}\mathrm{K}+\text { channel, Cyclic nucleotide } \\
\text { gated channel }\end{array}$ \\
\hline IL12-1 & Chr12: 74699.. 47436216, Chr12: 48239308.. 52930616 & $\begin{array}{l}\text { Huertas et al. } \\
\text { (2012) }\end{array}$ & SOS2 \\
\hline IL12-3 & N/A, AFLP data only & & \\
\hline \multicolumn{4}{|c|}{ Powdery mildew resistance } \\
\hline IL3-2 & Chr3: 1410013.. 57499392 & & \\
\hline IL4-2 & $\begin{array}{l}\text { Chr4: } 3071610 . .44938712 \text { (het), Chr4: } 46110324 . . \\
\quad 61886216\end{array}$ & & RLK, Ser/Threonine kinase \\
\hline IL4-3 & Chr4: 58808024.. 63693464, Chr9: 48774.. 3988469 & & $\begin{array}{l}\text { RLK, Ser/Threonine kinase, PAL, } \\
\text { PR1a, ACCox, EIN2 }\end{array}$ \\
\hline IL6-2 & Chr6: 37310260.. 40010168, Chr7: 56595944.. 61110872 & & $\begin{array}{l}\text { RLK, Ser/Threonine kinase, } \\
\text { Peroxidase, ACCox, }\end{array}$ \\
\hline
\end{tabular}


Table 1 continued

\begin{tabular}{|c|c|c|c|}
\hline Introgression lines & Genomic region (s) & References & Candidate genes \\
\hline IL9-1 & Chr9: 48774.. 3988469, Chr9: 62248928.. 67116024 (het) & & $\begin{array}{l}\text { NBS-LRR, RLK, PAL,PR1a, } \\
\text { ACCox, EIN2 }\end{array}$ \\
\hline IL12-3 & N/A, AFLP data only & & \\
\hline \multicolumn{4}{|c|}{ Powdery mildew resistance (salt stress) } \\
\hline IL4-2 & Chr4: $3071610 . .44938712$ (het), Chr4: $46110324 . .61886216$ & & \\
\hline IL4-3 & Chr4: 58808024.. 63693464, Chr9: 48774.. 3988469 & & \\
\hline IL9-1 & Chr9: 48774.. 3988469, Chr9: 62248928.. 67116024 (het) & & \\
\hline IL10-1 & Chr9: 48774.. 5464892, Chr10: 242877.. 49064720 & & \\
\hline
\end{tabular}

Table 2 Means $(\mathrm{n}=4)$ and range of measured ions in the parental and introgression lines under control (C) and salt stress treatment $(\mathrm{S})$

\begin{tabular}{|c|c|c|c|c|c|}
\hline & & \multirow{2}{*}{$\begin{array}{l}\text { MM } \\
\text { Mean } \pm \text { S.D. } \\
(\mathrm{mg} / \mathrm{g})\end{array}$} & \multirow[t]{2}{*}{ LYC4 } & \multicolumn{2}{|l|}{ ILs } \\
\hline & & & & $\begin{array}{l}\text { Mean } \\
(\mathrm{mg} / \mathrm{g})\end{array}$ & Range \\
\hline \multirow[t]{2}{*}{$\mathrm{Na}^{+}$} & c & $8.3 \pm 0.6$ & $11.6 \pm 2.8$ & 8.1 & $5.6-12.8$ \\
\hline & $\mathbf{s}$ & $25.6 \pm 3$ & $30.3 \pm 3.8$ & 22.7 & $18.2-29.2$ \\
\hline \multirow[t]{2}{*}{$\mathrm{K}^{+}$} & c & $34.3 \pm 4.7$ & $41.9 \pm 3$ & 34.4 & $26.9-41.2$ \\
\hline & $\mathbf{S}$ & $25.2 \pm 1.5$ & $25.6 \pm 2.7$ & 27.4 & $19.9-33$ \\
\hline \multirow[t]{2}{*}{$\mathrm{K} / \mathrm{Na}$} & c & $4.1 \pm 0.4$ & $3.8 \pm 1.1$ & 4.4 & $2.4-5.8$ \\
\hline & $\mathbf{s}$ & $1 \pm 0.05$ & $0.9 \pm 0.03$ & 1.2 & $0.74-1.67$ \\
\hline \multirow[t]{2}{*}{$\mathrm{Cl}^{-}$} & c & $12.1 \pm 2.1$ & $11.6 \pm 0.2$ & 11.8 & $7.9-19.2$ \\
\hline & $\mathbf{s}$ & $41.6 \pm 5.9$ & $44.3 \pm 7.1$ & 35.3 & $28.3-42.9$ \\
\hline \multirow[t]{2}{*}{$\mathrm{Ca}^{2+}$} & c & $11.1 \pm 0.7$ & $10.71 \pm 0.7$ & 10.9 & $8.6-14.8$ \\
\hline & $\mathbf{s}$ & $10.9 \pm 1.6$ & $11.8 \pm 2$ & 10.5 & $7.7-12.4$ \\
\hline \multirow[t]{2}{*}{$\mathrm{Mg}^{2+}$} & c & $12.7 \pm 0.4$ & $10.7 \pm 0.5$ & 11.9 & $8.9-15.5$ \\
\hline & $\mathbf{s}$ & $13.4 \pm 1.8$ & $14.3 \pm 2.1$ & 13.4 & $10.7-15$ \\
\hline \multirow[t]{2}{*}{$\mathrm{PO}_{4}^{3-}$} & c & $17.7 \pm 1.3$ & $22.7 \pm 1.8$ & 17.5 & $12.7-23.9$ \\
\hline & $\mathbf{s}$ & $14.5 \pm 1.5$ & $16.9 \pm 3.4$ & 15.8 & $11.2-19.5$ \\
\hline \multirow[t]{2}{*}{$\mathrm{SO}_{4}^{2-}$} & c & $20.6 \pm 1.4$ & $9.4 \pm 0.7$ & 17.7 & $12.5-24.4$ \\
\hline & $\mathbf{s}$ & $14.8 \pm 1.1$ & $11.4 \pm 1.9$ & 15.8 & 11.9-19.9 \\
\hline
\end{tabular}

non-stress conditions, however the degree of correlation $(r=0.7, p<0.001)$ suggests a considerable differential effect of salt stress on growth, supported by the statistically significant interaction observed between FW and stress levels in an ANOVA analysis $(\mathrm{p}<0.001)$. Relative growth under salt stress was strongly negatively correlated with growth under nonstressed conditions $(r=-0.54, p=0.0015)$, indicating that large plants on average are less tolerant to salt stress than smaller plants. Relative growth under salt stress was not correlated with any of the ions measured, except for $\mathrm{Na}^{+}$for which a weak positive correlation was observed $(\mathrm{r}=0.37, \mathrm{p}=0.039)$.
QTLs for powdery mildew resistance

Solanum habrochaites LYC4 exhibited a high level of resistance against PM, with limited disease symptoms (no HR observed). Several introgression lines (IL3-2, IL4-2, IL4-3, IL6-2, IL9-1 and IL12-3) had increased resistance compared to MM, however they were considerably more susceptible than LYC4 (mean DI range 2.2-3.0 compared to 4.0 for $\mathrm{MM}$ and 0.7 for LYC4, Figs. 2b, 3, Table 1). Partial resistance in IL32, which carries an introgression covering a large part of Chromosome 3, was characterized by the development of necrotic (HR-like) lesions at the site of fungal 
spore development. All other lines exhibited quantitative resistance with no visible cell death. IL4-3 and IL9-1 both carry a $\sim 4 \mathrm{Mbp}$ introgression at the top of Chr. 9. However, IL4-3 has an additional introgression at Chr. 4 that overlaps for $\sim 3 \mathrm{Mbp}$ with the introgressed segment of IL4-2, a line that was also more resistant. IL6-2 carries two introgressions of $\sim 2.7$ and 4.8 Mbp on chromosomes 6 and 7, respectively. The AFLP marker data point to a large introgression in IL12-3 at the bottom arm of Chr. 12.

Correlation analysis of DI with growth and ion content revealed a positive correlation with $\mathrm{FW}(\mathrm{r}=0.47$, $\mathrm{p}=0.006)$ and a negative with $\mathrm{PO}_{4}^{3-}$ content $(\mathrm{r}=$ $-0.31, p=0.047$ ), while no significant correlation was observed between DI and chlorophyll content.

\section{Combined salt and PM stresses}

Salt stress imposition significantly increased the susceptibility to PM of the population (mean DI of 4.45 compared to 3.65 without salt stress, $\mathrm{p}<0.001$ ). The effect was more pronounced when only the lines with significantly greater resistance than $\mathrm{MM}$ under either stress condition were included (ILs 3-2, 4-2, 4-3, 6-2, 9-1, 10-1 and 12-3, mean DI of 3.93 compared to 2.78 without salt stress, $\mathrm{p}<0.001)$.
Three out of four ILs identified with significantly reduced DI under combined stress conditions (ILs 4-2, 4-3 and 9-1) had also significantly reduced DI under non-salt stress conditions (Figs. 2c, 3; Table 1). Only IL10-1 exhibited increased resistance to PM uniquely under salt stress; it was only marginally (non-significantly) more resistant than MM under non-salt stress conditions.

To evaluate the effect of combinatorial stress on the phenotypic variation of the population for PM resistance, the coefficient of variation $(\mathrm{CV})$ values for DI were compared under PM and combined PM and salt stress. The CV under the combination of stresses was considerably lower than under PM infection (12.63\% compared to $18.92 \%$ ), which might indicate that the phenotypic variation for PM was reduced under salt stress (Fig. 4a). This could also be a result of the population susceptibility shifting towards the maximum of the disease score scale. However, when CV was calculated for the lines that were more resistant under either conditions a similar trend was observed $(14.53 \%$, mean $=3.93$ (combined stress) compared to $18.56 \%$, mean $=2.78$ (PM only), Fig. 4b).

No significant differences were observed between the ILs and MM for ion content under combined salt stress and therefore no QTLs could be assigned.

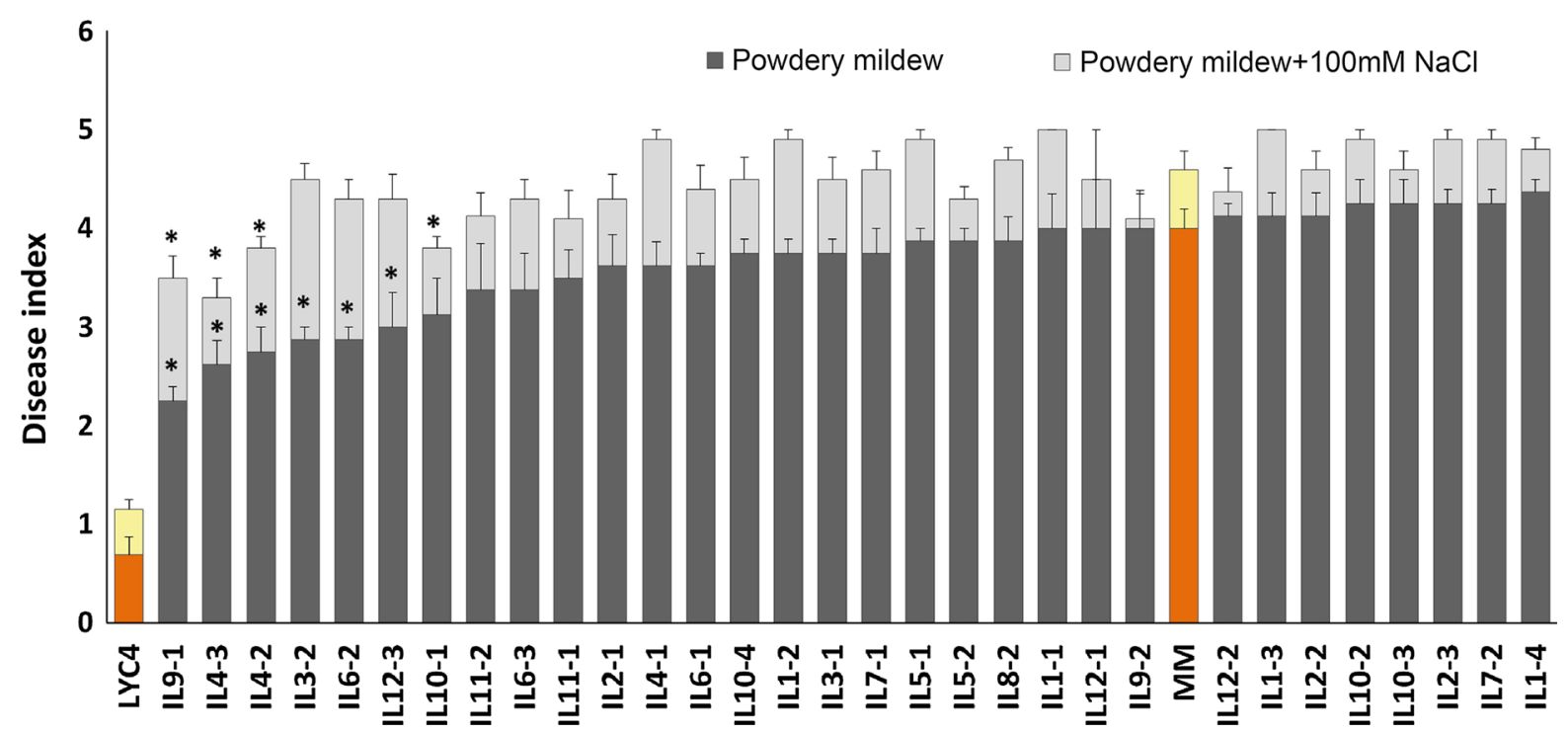

Fig. 3 PM resistance under control conditions (black bars) and under salt stress conditions (light grey bars) of the $31 \mathrm{~S}$. habrochaites LYC4 ILs and the two parental lines. The lines are in ascending order of susceptibility under non-salt stress conditions. Asterisks indicate significant differences between the introgression lines and the recurrent parent MM (Dunnett test, $\mathrm{p}<0.05$ ) 

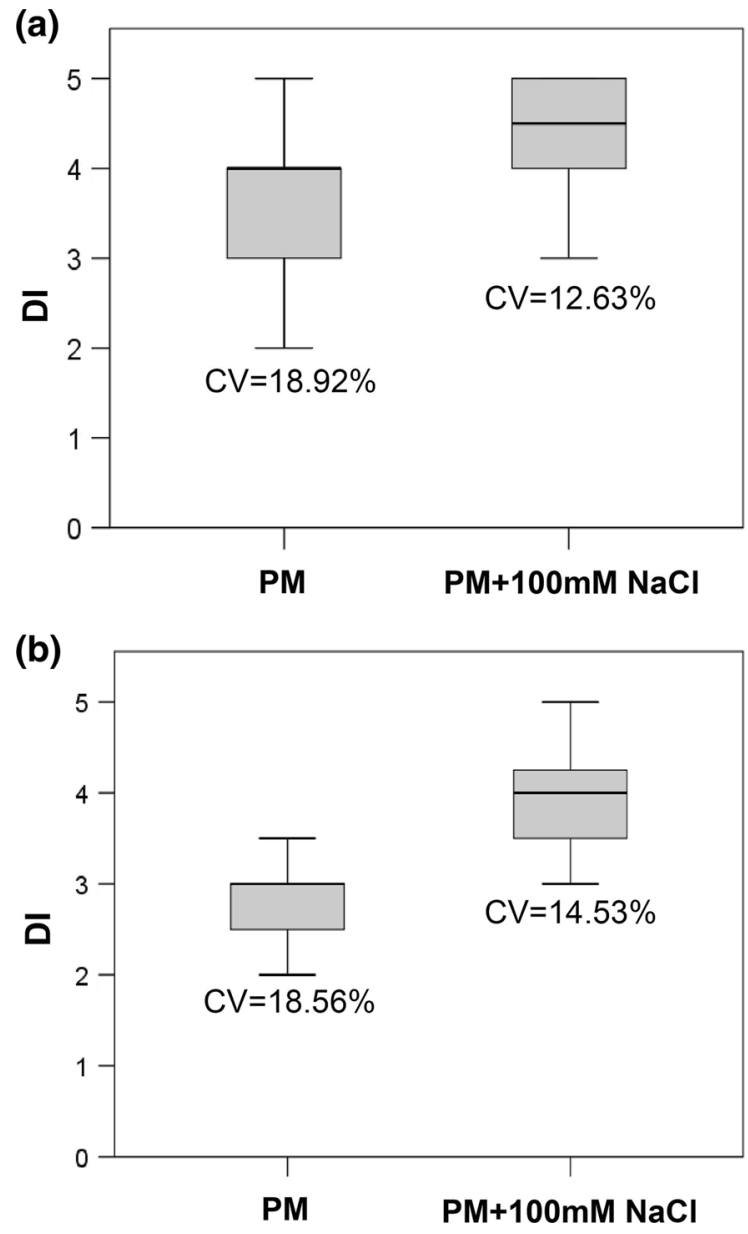

Fig. 4 Phenotypic variation of PM resistance under non-salt stress and salt stress conditions expressed as the coefficient of variation (CV) estimated in a the whole IL population (31 lines) b ILs more resistant compared to MM under either control or salt stress conditions (7 lines)

DI in non-salt stressed plants was significantly correlated with DI under combined stress $(r=0.77$, $\mathrm{p}<0.0001$, Fig. 5), suggesting minor interaction of salt stress with the genotypic differences in plant susceptibility, supported by the (marginally) non-significant ( $\mathrm{p}=0.092$ ) interaction observed, after ANOVA analysis. No further significant correlations were identified under combined stress, except a weak positive correlation of DI with chlorophyll content $(r=0.32)$.

\section{Discussion}

Salt stress and powdery mildew individually pose a significant threat to tomato production, and the

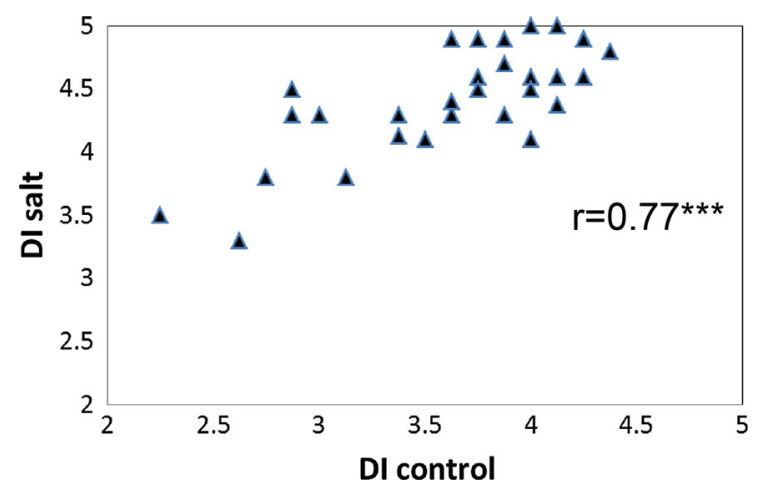

Fig. 5 Pearson correlation (r) between PM resistance (DI) under non-stress control conditions and under salt stress

probability of these occurring at the same time may result in non-additive effects on plant fitness. Therefore we examined the responses of the $S$. habrochaites LYC4 IL population to both separately applied salt stress and PM and the combination of these stresses. Even though the experiments were done in the greenhouse in a controlled environment, small differences in the environmental conditions between both experiments that influence the plants' performance and the measurements could not be avoided. Therefore, direct comparisons of the trait values measured in the two different experiments need to be done with caution. Nevertheless, QTL co-localization will be discussed, as most of the QTLs identified were reproducible in subsequent experiments with the selected ILs.

\section{S. habrochaites LYC4 carries significant variation for tolerance and ion homeostasis under salt stress}

Several S. habrochaites introgressions contributed significantly to salt tolerance, and our results indicate that under the stress conditions applied the IL lines that were larger in size were more affected by salt stress. The more vigorous (or high yielding) genotypes under non-stress conditions are often also the best-performing plants under mild stress in particular, with usually no crossover interactions (Blum 2005). The salt concentration applied in our experiments $(100 \mathrm{mM}$ $\mathrm{NaCl}$ ) is considered to exceed this crossover point for tomato (Maggio et al. 2007). This is supported by the significant interactions between plant biomass and salinity level and the moderate correlation between plant biomass under control and salt stress conditions. Interestingly, two ILs with higher FW than the 
recurrent parent $\mathrm{MM}$ under both control and salt stress (IL3-2 and 2-3) also exhibited a higher salt tolerance index. These properties make them valuable starting material for salt tolerance breeding, especially IL2-3 which was previously shown to out-yield, under control conditions, the parental line MM while IL3-2 had substantially lower fruit yields (Finkers 2007).

Several genomic regions of LYC4 contributed to an increased salt tolerance index. Many of the QTLs identified in this study co-localized with previously discovered stress tolerance-contributing loci in segregating populations derived from crosses with wild tomato species (Table 1). The introgressed region in Chr. 1 of IL2-3 coincides with QTLs identified in previous studies for enhanced germination, vegetative growth and fruit yield under salt stress (Foolad 1999; Villalta et al. 2007). In this region, many candidate genes reside that are involved in the regulation of ion homeostasis, such as NHX3, NHX4 and SOS1 (Gálvez et al. 2012; Olías et al. 2009), and for redox homeostasis such as $\mathrm{Cu} / \mathrm{ZnSOD} 1$ (Chen et al. 2009). Notably, IL2-3 exhibited lower $\mathrm{Na}^{+}$accumulation (19.9 mg/g compared to $25.5 \mathrm{mg} / \mathrm{g}$ dry biomass of $\mathrm{MM}$ ), but it was marginally below the significance cutoff level and therefore no QTL was assigned. An introgressed segment from Chr. 7 present in IL8-2 had the strongest association with salt tolerance index. Two HKT genes were recently found to reside on Chr. 7, potentially being causal for a QTL controlling $\mathrm{Na}^{+}$ and $\mathrm{K}^{+}$concentration (Asins et al. 2013). However the introgression of IL8-2 covers almost the whole Chr.7, so linking it with the HKT function should be done with caution. IL8-2 also exhibited significantly lower $\mathrm{Cl}^{-}$accumulation, which was shown to contribute to salt tolerance in barley (Tavakkoli et al. 2011).

The introgressed segments on chromosomes 9, 10 and 12 found in the IL set used for this study are relatively small. IL9-1 exhibited higher levels of $\mathrm{K}^{+}$, as well as higher $\mathrm{K} / \mathrm{Na}$ ratio compared to $\mathrm{MM}$ under salt stress. A putative potassium channel, and cyclic nucleotide gated channels involved in $\mathrm{K}^{+}$transport (Shabala and Cuin 2008) reside in the introgressed region of this line as well as other genes involved in plant stress responses. (Table 1). The introgressed region on Chr. 10 contains ethylene response factors (ERFs) involved in stress tolerance and growth regulation under abiotic stress (Cheng et al. 2013; Dubois et al. 2013) as well as aquaporins, GSTs and RLKs.
No correlation was found between salt tolerance index and ion content, except for $\mathrm{Na}^{+}$accumulation, which was weakly positively correlated. The lack of correlation is evidenced by the limited co-localization of QTLs for salt tolerance index and ion content (Supp. Table 4), as well as the insignificant contribution to salt tolerance of a shared introgression in $\mathrm{Chr}$. 12, resulting in lower $\mathrm{Na}^{+}$accumulation, carried by ILs 12-1 and 12-3. The type and the size of the population may have limited the discovery of correlations, as usually unique introgressions are present in the different ILs, which despite the possibility of coregulating different traits, is present in only a few individuals of the population, resulting in non-statistically significant associations. However previous studies have as well identified a non-significant correlation of $\mathrm{Na}^{+}$accumulation with salt stress tolerance in tomato (Rao et al. 2013; Villalta et al. 2008). In fact, $\mathrm{Na}^{+}$can be used as an osmoticum facilitating water status maintenance, as it was observed in S. pimpinellifolium (Bolarin et al. 2001). and this is reflected as well in our results where LYC4 is more tolerant compared to $\mathrm{MM}$ despite having higher $\mathrm{Na}^{+}$accumulation, suggesting that $\mathrm{Na}^{+}$tissue tolerance (by storing $\mathrm{Na}^{+}$in the vacuole or older leaves) contributes to LYC4 salt tolerance. On the other hand the lack of co-localization between many salt tolerance and ion content QTLs, offers the opportunity to combine them through pyramiding and examine epistatic interactions that additionally affect salt tolerance.

\section{S. habrochaites LYC4 introgression contribute to partial resistance to powdery mildew}

Solanum habrochaites LYC4 exhibited a high level of resistance to PM. None of the introgression lines exhibited the same level of resistance. This phenomenon was also observed in a previous study of this IL population on resistance to Botrytis cinerea (Finkers et al. 2007b). It can be either a result of incomplete representation of the wild species genome in the IL population, or the breakdown of epistatic interactions between loci, which are common in plant defense signaling (Alcázar et al. 2009). Resistance to PM in LYC4 is not the result of HR. In addition LYC4 was previously found to be resistant to various pathogens and insects (Finkers et al. 2007a; Yu et al. 2010). Therefore increased basal resistance, or secretion of 
secondary metabolites (antibiosis) and leaf surface structure such as the trichomes (antixenosis), may contribute to resistance (Nonomura et al. 2009), which should be further examined in this population.

Introgressions conferring PM resistance do not coincide with previously identified regions with PM resistance genes (Li et al. 2007, 2012). All previously identified genes confer strong resistance to PM, in contrast to the QTLs reported here. Because of the size of the introgressions, no specific genes can be pinpointed for increased resistance, though several candidate genes are present (Table 1), on many occasions (such as the RLKs) in multiple copies.

Salinity stress has a negative impact on powdery mildew resistance

Salt stress (100 mM) increased PM susceptibility in all genotypes of the population. This is in agreement with the majority of studies in literature reporting a suppressive effect of abiotic stress on defense responses and increase in susceptibility. In Arabidopsis thaliana abiotic stressors were shown to suppress various aspects of the defense response. Salt stress inhibited salicylic acid (SA) biosynthesis and the induction of systemic acquired resistance (Yasuda et al. 2008), while drought and heat stress suppressed basal and R-gene mediated resistance against a virus (Prasch and Sonnewald 2013). Contrarily, a previous study in tomato reported a weak positive effect of salt stress (100 mM) on PM resistance (Achuo et al. 2006). These observations can be a result of the longer period the plants experienced salt stress (14 days vs 7 in our study), which may have allowed a buildup of $\mathrm{Na}^{+}$and $\mathrm{Cl}^{-}$concentration to toxic for the fungus levels We have observed a significant positive impact of $\mathrm{Na}^{+}$and $\mathrm{Cl}^{-}$accumulation on powdery mildew resistance in experiments with varied salt stress levels, with mild salt stress increasing susceptibility while stronger salt stress is reversing the effect (unpublished results).

Powdery mildew resistance QTLs were fewer under combined salt stress than under only PM stress alone but they were mostly shared between the two treatments. This result, in conjunction with the high correlation of DI between both conditions, indicates that salinity stress had a general suppressive effect on the defense response rather than a specific interaction. Observations from molecular studies further support this conclusion, as several components of the defense signaling network appear to be down-regulated under abiotic stress (Mang et al. 2012; Prasch and Sonnewald 2013). Both the fewer QTLs identified as well the reduced phenotypic variability of $\mathrm{PM}$ resistance under combined stress point to a negative impact of salt stress on the expression of genotypic variation under these conditions, potentially altering the adaptive potential/fitness. Phenotypic plasticity is considered pivotal in the plant's ability to adapt to changing environments (Ghalambor et al. 2007; Nicotra et al. 2010), and a reduction of this phenotypic plasticity when exposed to multiple stresses can have additional detrimental effects on plants and crop productivity. Moreover, it highlights an additional aspect that may pose a challenge for breeding for resistance to combined stresses: reduction in phenotypic variation can negatively affect selection efficiency when resistance is partial or quantitatively controlled. On the other hand selection for increased resistance under combined stress can be more robust when resistance is controlled by a single (or few) R-genes as it can quickly eliminate R-genes that become non functional under these conditions.

$\mathrm{Na}^{+}$and $\mathrm{Cl}^{-}$accumulation under salt stress can have a harmful effect on both the host and the pathogen (Blomberg and Adler 1993). However, no significant correlation between disease severity and $\mathrm{Na}^{+}$and $\mathrm{Cl}^{-}$ accumulation was found in our study. It is possible that the concentration of $\mathrm{NaCl}$ applied did not result in the accumulation of $\mathrm{Na}^{+}$and $\mathrm{Cl}^{-}$up to levels that were toxic for the fungus (evidenced by the increased fungal growth under salt stress). The severity of the stress can influence the magnitude of impact of another stress (Soliman and Kostandi 1998). Preliminary results in our laboratory indicated that the impact of salt stress on PM growth may depend on the severity of the applied stress (unpublished results). The lack of correlation of internal salt accumulation with PM growth may therefore be explained by relatively low (subtoxic) levels of $\mathrm{Na}^{+}$ and $\mathrm{Cl}$ Alternatively, the genetic variability in the population for $\mathrm{Na}^{+}$and $\mathrm{Cl}^{-}$accumulation and/or disease resistance may be too limited, as evidenced by the small number of QTLs identified under salt stress alone and none under stress combination. In addition, the weak positive correlation between DI and chlorophyll content may point to the significance of nutrient availability for fungal growth, and could be indicative of the negative interaction between salt tolerance and disease under combined stress. Salt tolerance is often 
characterized by delayed senescence and the maintenance of chlorophyll, a nitrogenous compound, under stress can positively interact with pathogen growth by facilitating (biotrophic) pathogen nutrition (Walters and Bingham 2007).

Our data point to distinct genetic architectures for salt stress tolerance and PM resistance in the LYC4 IL population, with few QTLs shared (Supp. Table 3) and no significant correlations observed. The shared QTLs are relatively large, with possibly different genes being responsible for resistance to either stress. The introgression of IL9-1 (resistant under all stress conditions), may contribute to multiple stress tolerance. Although there are genes present in the introgressed region that have a clear function in pathogen response and resistance (RLKs, PRs, PAL), there are also multiple genes encoding TFs, redox and ethylene signaling components that have broad functions in stress responses. Therefore, further dissection of multiple and combined stress tolerance in IL9-1 is needed, using different approaches such as fine mapping, transcriptomics analyses and reverse genetics.

In conclusion, several genomic regions were identified in the $S$. habrochaites LYC4 IL population that can contribute to salt stress tolerance and PM resistance in tomato. Salt stress predisposed plants towards increased susceptibility to PM. The reduction in phenotypic variation under stress combination may have additional implications on plant and crop performance and breeding efforts. As no correlation was observed between salt stress tolerance and PM resistance, the different components appear to not interact with each other. Therefore a strategy of combining resistance and tolerance traits may be successful. With the availability of the tomato genome sequence and high throughput phenotypic analyses, phenotypic responses and tolerance to stress combination can be precisely associated with the genotype and breeding of combinatorial stress resilient crops may be feasible.

Acknowledgments Christos Kissoudis is supported by "Alexander S. Onassis" Public Benefit Foundation scholarship.

Open Access This article is distributed under the terms of the Creative Commons Attribution License which permits any use, distribution, and reproduction in any medium, provided the original author(s) and the source are credited.

\section{References}

Achuo EA, Prinsen E, Hofte M (2006) Influence of drought, salt stress and abscisic acid on the resistance of tomato to Botrytis cinerea and Oidium neolycopersici. Plant Pathol 55:178-186

Alcázar R, García AV, Parker JE, Reymond M (2009) Incremental steps toward incompatibility revealed by Arabidopsis epistatic interactions modulating salicylic acid pathway activation. Proc Natl Acad Sci USA 106:334-339

Al-Sadi AM, Al-Masoudi RS, Al-Habsi N, Al-Said FA, Al-Rawahy SA, Ahmed M, Deadman ML (2010) Effect of salinity on pythium damping-off of cucumber and on the tolerance of Pythium aphanidermatum. Plant Pathol 59:112-120

Asano T, Hayashi N, Kobayashi M, Aoki N, Miyao A, Mitsuhara I, Ichikawa H, Komatsu S, Hirochika H, Kikuchi S, Ohsugi R (2012) A rice calcium-dependent protein kinase OsCPK12 oppositely modulates salt-stress tolerance and blast disease resistance. Plant J 69:26-36

Asins MJ, Villalta I, Aly MM, Olías R, Álvarez De Morales P, Huertas R, Li J, Jaime-Pérez N, Haro R, Raga V, Carbonell EA, Belver A (2013) Two closely linked tomato HKT coding genes are positional candidates for the major tomato QTL involved in $\mathrm{Na}^{+} / \mathrm{K}^{+}$homeostasis. Plant Cell Environ 36:1171-1191

Atkinson NJ, Lilley CJ, Urwin PE (2013) Identification of genes involved in the response of arabidopsis to simultaneous biotic and abiotic stresses. Plant Physiol 162:2028-2041

Bai Y, Huang CC, Van Der Hulst R, Meijer-Dekens F, Bonnema G, Lindhout P (2003) QTLs for tomato powdery mildew resistance (Oidium lycopersici) in Lycopersicon parviflorum G1.1601 co-localize with two qualitative powdery mildew resistance genes. Mol Plant Microbe Interact 16:169-176

Blomberg A, Adler L (1993) Tolerance of fungi to NaCl. Stress tolerance of fungi, pp 209-232

Blum A (2005) Drought resistance, water-use efficiency, and yield potential-are they compatible, dissonant, or mutually exclusive? Crop Pasture Sci 56:1159-1168

Bolarin MC, Estañ MT, Caro M, Romero-Aranda R, Cuartero J (2001) Relationship between tomato fruit growth and fruit osmotic potential under salinity. Plant Sci 160:1153-1159

Chen S, Gollop N, Heuer B (2009) Proteomic analysis of saltstressed tomato (Solanum lycopersicum) seedlings: effect of genotype and exogenous application of glycinebetaine. J Exp Bot 60:2005-2019

Cheng MC, Liao PM, Kuo WW, Lin TP (2013) The arabidopsis ETHYLENE RESPONSE FACTOR1 regulates abiotic stress-responsive gene expression by binding to different cis-acting elements in response to different stress signals. Plant Physiol 162:1566-1582

Chibon P, Schoof H, Visser RG, Finkers R (2012) Marker2sequence, mine your QTL regions for candidate genes. Bioinformatics 28:1921-1922

Coakley SM, Scherm H, Chakraborty S (1999) Climate change and plant disease management. Annu Rev Phytopathol 37:399-426 
Cuartero J, Bolarín MC, Asíns MJ, Moreno V (2006) Increasing salt tolerance in the tomato. J Exp Bot 57:1045-1058

Dai A (2013) Increasing drought under global warming in observations and models. Nat Clim Chang 3:52-58

Dubois M, Skirycz A, Claeys H, Maleux K, Dhondt S, De Bodt S, vanden Bossche R, De Milde L, Yoshizumi T, Matsui M, Inzé D (2013) ETHYLENE RESPONSE FACTOR6 acts as a central regulator of leaf growth under water-limiting conditions in Arabidopsis. Plant Physiol 162:319-332

Dunnett CW (1955) A multiple comparison procedure for comparing several treatments with a control. J Am Stat Assoc 50:1096-1121

Finkers R (2007) The genetics of Botrytis cinerea resistance in tomato. Wageningen University, Wageningen, p 126

Finkers R, Van Den Berg P, Van Berloo R, Ten Have A, Van Heusden AW, Van Kan JAL, Lindhout P (2007a) Three QTLs for Botrytis cinerea resistance in tomato. Theor Appl Genet 114:585-593

Finkers R, Van Heusden AW, Meijer-Dekens F, Van Kan JAL, Maris P, Lindhout P (2007b) The construction of a Solanum habrochaites LYC4 introgression line population and the identification of QTLs for resistance to Botrytis cinerea. Theor Appl Genet 114:1071-1080

Foolad MR (1999) Comparison of salt tolerance during seed germination and vegetative growth in tomato by QTL mapping. Genome 42:727-734

Gálvez FJ, Baghour M, Hao G, Cagnac O, Rodríguez-Rosales MP, Venema K (2012) Expression of LeNHX isoforms in response to salt stress in salt sensitive and salt tolerant tomato species. Plant Physiol Biochem 51:109-115

Garrett KA, Dendy SP, Frank EE, Rouse MN, Travers SE (2006) Climate change effects on plant disease: genomes to ecosystems. Annu Rev Phytopathol 44:489-509

Ghalambor CK, McKay JK, Carroll SP, Reznick DN (2007) Adaptive versus non-adaptive phenotypic plasticity and the potential for contemporary adaptation in new environments. Funct Ecol 21:394-407

Gorguet B, Eggink PM, Ocaña J, Tiwari A, Schipper D, Finkers R, Visser RGF, Van Heusden AW (2008) Mapping and characterization of novel parthenocarpy QTLs in tomato. Theor Appl Genet 116:755-767

Grandillo S, Chetelat R, Knapp S, Spooner D, Peralta I, Cammareri M, Perez O, Termolino P, Tripodi P, Chiusano ML, Ercolano MR, Frusciante L, Monti L, Pignone D (2011) Solanum sect. Lycopersicon. Wild crop relatives: genomic and breeding resources, vegetables: 129-215

Harvell CD, Mitchell CE, Ward JR, Altizer S, Dobson AP, Ostfeld RS, Samuel MD (2002) Climate warming and disease risks for terrestrial and marine biota. Science 296:2158-2162

Huang CC, Hoefs-van de Putte PM, Haanstra-van der Meer JG, Meijer-Dekens F, Lindhout P (2000) Characterization and mapping of resistance to Oidium lycopersicum in two Lycopersicon hirsutum accessions: evidence for close linkage of two Ol-genes on chromosome 6 of tomato. Heredity 85:511-520

Huertas R, Olías R, Eljakaoui Z, Gálvez FJ, Li J, De Morales PA, Belver A, Rodríguez-Rosales MP (2012) Overexpression of SISOS2 (SICIPK24) confers salt tolerance to transgenic tomato. Plant Cell Environ 35:1467-1482
Jones H, Whipps JM, Gurr SJ (2001) The tomato powdery mildew fungus Oidium neolycopersici. Mol Plant Pathol 2:303-309

Jordan WR, Clark RB, Seetharama N (1984) The role of edaphic factors in disease development. In: Proceedings of the consultative group discussion on research needs and strategies for control of Sorghum root and stalk rot diseases, pp 81-97

Kissoudis C, van de Wiel C, Visser RGF, Van Der Linden G (2014) Enhancing crop resilience to combined abiotic and biotic stress through the dissection of physiological and molecular crosstalk. Front Plant Sci 5:207

Li C, Bonnema G, Che D, Dong L, Lindhout P, Visser R, Bai Y (2007) Biochemical and molecular mechanisms involved in monogenic resistance responses to tomato powdery mildew. Mol Plant Microbe Interact 20:1161-1172

Li J, Liu L, Bai Y, Zhang P, Finkers R, Du Y, Visser RGF, van Heusden AW (2011) Seedling salt tolerance in tomato. Euphytica 178:403-414

Li C, Faino L, Dong L, Fan J, Kiss L, de Giovanni C, Lebeda A, Scott J, Matsuda Y, Toyoda H, Lindhout P, Visser RGF, Bonnema G, Bai Y (2012) Characterization of polygenic resistance to powdery mildew in tomato at cytological, biochemical and gene expression level. Mol Plant Pathol 13:148-159

Maggio A, Raimondi G, Martino A, De Pascale S (2007) Salt stress response in tomato beyond the salinity tolerance threshold. Environ Exp Bot 59:276-282

Mang HG, Qian W, Zhu Y, Qian J, Kang HG, Klessig DF, Hua J (2012) Abscisic acid deficiency antagonizes high-temperature inhibition of disease resistance through enhancing nuclear accumulation of resistance proteins SNC1 and RPS4 in Arabidopsis. Plant Cell 24:1271-1284

Mittler R (2006) Abiotic stress, the field environment and stress combination. Trends Plant Sci 11:15-19

Munns R, Tester M (2008) Mechanisms of salinity tolerance. Annu Rev Plant Biol 59:651-681

Nicotra AB, Atkin OK, Bonser SP, Davidson AM, Finnegan EJ, Mathesius U, Poot P, Purugganan MD, Richards CL, Valladares F, van Kleunen M (2010) Plant phenotypic plasticity in a changing climate. Trends Plant Sci 15:684692

Nonomura T, Xu L, Wada M, Kawamura S, Miyajima T, Nishitomi A, Kakutani K, Takikawa Y, Matsuda Y, Toyoda H (2009) Trichome exudates of Lycopersicon pennellii form a chemical barrier to suppress leaf-surface germination of Oidium neolycopersici conidia. Plant Sci 176:31-37

OlÍas R, Eljakaoui Z, Li J, De Morales PA, MarÍn-Manzano MC, Pardo JM, Belver A (2009) The plasma membrane $\mathrm{Na}^{+} / \mathrm{H}^{+}$antiporter SOS1 is essential for salt tolerance in tomato and affects the partitioning of $\mathrm{Na}^{+}$between plant organs. Plant Cell Environ 32:904-916

Peters GP, Marland G, Le Qúeŕe C, Boden T, Canadell JG, Raupach MR (2011) Rapid growth of $\mathrm{CO}_{2}$ emission after the 2008-2009 global financial crisis. Nat Clim Chang 2: $1-3$

Prasch CM, Sonnewald U (2013) Simultaneous application of heat, drought, and virus to Arabidopsis plants reveals significant shifts in signaling networks. Plant Physiol 162: 1849-1866 
Ramírez V, Coego A, López A, Agorio A, Flors V, Vera P (2009) Drought tolerance in Arabidopsis is controlled by the OCP3 disease resistance regulator. Plant J 58:578-591

Ranjan A, Ichihashi Y, Sinha NR (2012) The tomato genome: implications for plant breeding, genomics and evolution. Genome Biol 13:167

Rao ES, Kadirvel P, Symonds RC, Ebert AW (2013) Relationship between survival and yield related traits in Solanum pimpinellifolium under salt stress. Euphytica 190:215-228

Rasmussen S, Barah P, Suarez-Rodriguez MC, Bressendorff S, Friis P, Costantino P, Bones AM, Nielsen HB, Mundy J (2013) Transcriptome responses to combinations of stresses in Arabidopsis. Plant Physiol 161:1783-1794

Roubtsova TV, Bostock RM (2009) Episodic abiotic stress as a potential contributing factor to onset and severity of disease caused by Phytophthora ramorum in Rhododendron and Viburnum. Plant Dis 93:912-918

Sanogo S (2004) Response of chile pepper to Phytophthora capsici in relation to soil salinity. Plant Dis 88:205-209

Sato S, Tabata S, Hirakawa H, Asamizu E, Shirasawa K, Isobe S, Kaneko T, Nakamura Y, Shibata D, Aoki K, Egholm M, Knight J, Bogden R, Li C, Shuang Y, Xu X, Pan S, Cheng S, Liu X, Ren Y, Wang J, Albiero A, Dal Pero F, Todesco S, Van Eck J, Buels RM, Bombarely A, Gosselin JR, Huang M, Leto JA, Menda N, Strickler S, Mao L, Gao S, Tecle IY, York T, Zheng Y, Vrebalov JT, Lee J, Zhong S, Mueller LA, Stiekema WJ, Ribeca P, Alioto T, Yang W, Huang S, Du Y, Zhang Z, Gao J, Guo Y, Wang X, Li Y, He J, Cheng Z, Zuo J, Ren J, Zhao J, Yan L, Jiang H, Wang B, Li H, Li Z, Fu F, Chen B, Han B, Feng Q, Fan D, Wang Y, Ling H, Xue Y, Ware D, McCombie WR, Lippman ZB, Chia JM, Jiang K, Pasternak S, Gelley L, Kramer M, Anderson LK, Chang SB, Royer SM, Shearer LA, Stack SM, Rose JKC, Xu Y, Eannetta N, Matas AJ, McQuinn R, Tanksley SD, Camara F, Guigó R, Rombauts S, Fawcett J, Van De Peer Y, Zamir D, Liang C, Spannagl M, Gundlach H, Bruggmann R, Mayer K, Jia Z, Zhang J, Ye Z, Bishop GJ, Butcher S, Lopez-Cobollo R, Buchan D, Filippis I, Abbott J, Dixit IR, Singh M, Singh A, Pal JK, Pandit A, Singh PK, Mahato AK, Dogra V, Gaikwad K, Sharma TR, Mohapatra T, Singh NK, Causse M, Rothan C, Noirot C, Bellec A, Klopp C, Delalande C, Berges H, Mariette J, Frasse P, Vautrin S, Zouine TM, Latché A, Rousseau C, Regad F, Pech JC, Philippot M, Bouzayen M, Pericard P, Osorio S, Del Carmen AF, Monforte A, Granell A, Fernandez-Muñoz R, Conte M, Lichtenstein G, Carrari F, De Bellis G, Fuligni F, Peano C, Grandillo S, Termolino P, Pietrella M, Fantini E, Falcone G, Fiore A, Giuliano G, Lopez L, Facella P, Perrotta G, Daddiego L, Bryan G, Orozco BM, Pastor X, Torrents D, Van Schriek MGM, Feron RMC, Van Oeveren J, De Heer P, Da Ponte L, Jacobs-Oomen S, Cariaso M, Prins M, Van Eijk MJT, Janssen A, Van Haaren JJ, HwanJo S, Kim J, Kwon SY, Kim S, Koo DH, Lee S, Clouser C, Rico A, Hallab A, Gebhardt C, Klee K, Jöcker A, Warfsmann J, Göbel U, Kawamura S, Yano E, Sherman JD, Fukuoka H, Negoro S, Bhutty S, Chowdhury P, Chattopadhyay D, Datema E, Smit S, Schijlen EGWM, Van De Belt J, Van Haarst JC, Peters SA, Van Staveren MJ, Henkens MHC, Mooyman PJW, Hesselink T, Van Ham RCHJ, Jiang G, Droege M, Choi D, Kang BC, Kim BD, Park M, Yeom SI, Lee YH, Choi YD,
Li G, Liu Y, Fernandez-Pedrosa V, Collado C, Zuñ Iga S, Wang G, Cade R, Dietrich RA, Rogers J, Knapp S, Fei Z, White RA, Thannhauser TW, Giovannoni JJ, Botella MA, Gilbert L, Gonzalez FR, Goicoechea JL, Yu Y, Kudrna D, Collura K, Wissotski M, Wing R, Meyers BC, Gurazada AB, Green PJ, Mathur S, Vyas S, Solanke AU, Kumar R, Gupta V, Sharma AK, Khurana P, Khurana JP, Tyagi AK, Dalmay T, Mohorianu I, Walts B, Chamala S, Barbazuk WB, Li J, Guo H, Lee TH, Zhang D, Paterson AH, Tang H, Barone A, Chiusano ML, Ercolano MR, D’Agostino N, Di Filippo M, Traini A, Sanseverino W, Frusciante L, Seymour GB, Elharam M, Fu Y, Hua A, Kenton S, Lewis J, Lin S, Najar F, Lai H, Qin B, Shi R, Qu C, White D, White J, Xing Y, Yang K, Yi J, Yao Z, Zhou L, Roe BA, Vezzi A, D'Angelo M, Zimbello R, Schiavon R, Caniato E, Rigobello C, Campagna D, Vitulo N, Valle G, Nelson DR, De Paoli E, Szinay D, De Jong HH, Bai Y, Visser RGF, Lankhorst RK, Beasley H, McLaren K, Nicholson C, Riddle C, Gianese G (2012) The tomato genome sequence provides insights into fleshy fruit evolution. Nature 485:635-641

Shabala S, Cuin TA (2008) Potassium transport and plant salt tolerance. Physiol Plant 133:651-669

Soliman MF, Kostandi SF (1998) Effect of saline environment on yield and smut disease severity of different corn genotypes (Zea mays L.). J Phytopathol 146:185-189

Tavakkoli E, Fatehi F, Coventry S, Rengasamy P, McDonald GK (2011) Additive effects of $\mathrm{Na}^{+}$and $\mathrm{Cl}^{-}$ions on barley growth under salinity stress. J Exp Bot 62:2189-2203

Triky-Dotan S, Yermiyahu U, Katan J, Gamliel A (2005) Development of crown and root rot disease of tomato under irrigation with saline water. Phytopathology 95:1438-1444

Van Berloo R (2008) GGT 2.0: versatile software for visualization and analysis of genetic data. J Hered 99:232-236

Venema JH, Dijk BE, Bax JM, van Hasselt PR, Elzenga JTM (2008) Grafting tomato (Solanum lycopersicum) onto the rootstock of a high-altitude accession of Solanum habrochaites improves suboptimal-temperature tolerance. Environ Exp Bot 63:359-367

Villalta I, Bernet GP, Carbonell EA, Asins MJ (2007) Comparative QTL analysis of salinity tolerance in terms of fruit yield using two solanum populations of F7 lines. Theor Appl Genet 114:1001-1017

Villalta I, Reina-Sánchez A, Bolarín MC, Cuartero J, Belver A, Venema K, Carbonell EA, Asins MJ (2008) Genetic analysis of $\mathrm{Na}^{+}$and $\mathrm{K}^{+}$concentrations in leaf and stem as physiological components of salt tolerance in tomato. Theor Appl Genet 116:869-880

Víquez-Zamora M, Vosman B, van de Geest H, Bovy A, Visser RGF, Finkers R, van Heusden AW (2013) Tomato breeding in the genomics era: insights from a SNP array. BMC Genomics 14:354

Walters DR, Bingham IJ (2007) Influence of nutrition on disease development caused by fungal pathogens: implications for plant disease control 151:307-324

Wiese J, Kranz T, Schubert S (2004) Induction of pathogen resistance in barley by abiotic stress. Plant Biol (Stuttg) 6:529-536

Yasuda M, Ishikawa A, Jikumaru Y, Seki M, Umezawa T, Asami T, Maruyama-Nakashita A, Kudo T, Shinozaki K, Yoshida S, Nakashita H (2008) Antagonistic interaction 
between systemic acquired resistance and the abscisic acidmediated abiotic stress response in Arabidopsis. Plant Cell 20:1678-1692

You MP, Colmer TD, Barbetti MJ (2011) Salinity drives host reaction in Phaseolus vulgaris (common bean) to Macrophomina phaseolina. Funct Plant Biol 38:984-992

Yu G, Nguyen TTH, Guo Y, Schauvinhold I, Auldridge ME, Bhuiyan N, Ben-Israel I, Iijima Y, Fridman E, Noel JP,
Pichersky E (2010) Enzymatic functions of wild tomato methylketone synthases 1 and 2. Plant physiol 154:67-77 Zhao MS, Running SW (2010) Drought-induced reduction in global terrestrial net primary production from 2000 through 2009. Science 329:940-943 